\section{DANUTA KĘPA-FIGURA}

Uniwersytet Marii Curie Skłodowskiej, Lublin, Poland https://orcid.org/0000-0001-8753-6980
Copyright and License: Copyright by Instytut Języka Polskiego PAN, Kraków 2021. This article is published under the terms of the Creative Commons Attribution - NoDerivatives 4.0 International (CC BY- ND 4.0) License (https:// creativecommons.org/licenses/by-nd/4.0/legalcode.pl).

\title{
LINGUISTIC POLITENESS IN POLISH SOCIAL MEDIA - AN OVERVIEW OF THE PROBLEM
}

Keywords: linguistic politeness, social media, Facebook.

\begin{abstract}
The main objective of this article is to formulate the principles of linguistic politeness that are operative in Polish social media (SM). The analysis focuses on the most popular SM in Poland - Facebook. The research has shown that the form of linguistic politeness operative in SM depends on: technical functionality; talking about oneself and using indirect speech acts is a commonly accepted behaviour in SM; verbal and non-verbal messages are considered equivalent acts of linguistic politeness; the most important cultural principles underlying linguistic politeness in SM are an orientation towards sincerity of conversation and a ridiculing attitude towards reality. Although the manifestations of the traditional and the social media model of linguistic politeness differ, both use the same communication script: conforming to the expectations of the recipient.
\end{abstract}

\section{RESEARCH PROBLEM}

The main objective of this paper is to formulate the principles of linguistic politeness that apply in Polish social media. An additional, operational purpose of the paper is to verify whether it is justified to think about linguistic politeness in terms of a category pertaining to language-based methods of building interpersonal relations. As a result, conclusions are drawn about the essence of communication through verbal messages exchanged in the social media environment.

The scope of the discussion indicated by the title of the article is delineated by three variables. The first variable is my way of understanding the notion of social media. The second is the choice of the analytical material, while the third is my way of understanding the notion of linguistic politeness. 


\subsection{The way of understanding the notion of social media}

The concept of social media is used not only as a professional, but also as a popular construct. I can illustrate the professional understanding of social media with a quote from Wikipedia (because it is a collection of texts created by people for whom the Internet constitutes a natural environment). I will also take into account definitions available in research papers devoted to the subject of social media. Some studies (cf. Kaplan and Haenlein 2010; Koszembar-Wiklik 2015) assume that social media are Internet applications based on the ideological and technological foundations of Web 2.0 that enable the creation and exchange of content generated by users. Wikipedia, on the other hand, proposes that social media be defined as:

"solutions using online and mobile technologies, allowing communication through interactive dialogue", "social media technologies" were defined as "social networks, blogs, business social networks, discussion forums, microblogs, photo and video sharing sites, as well as reviewing products/services, social bookmarks" [Wikipedia, accessed March 28, 2021]1'.

Paul Levinson narrows the scope of the concept of social media to blogs, YouTube, Wikipedia and social networking sites (Facebook, Twitter, etc.) (Levinson 2010).

Analysis of the definitions of social media allows for the identification of two categorisation paths that are activated when talking about social media from a professional perspective: 'specific Internet technologies', and 'specific activities (actions) taken by Internet users' (along with a yet narrower definition of 'selected forms of specific Internet users' activities').

Interestingly enough, the professional understanding of social media can also be found in the online dictionary of Polish (Stownik języka polskiego PWN): "Internet and mobile technologies enabling contact between users through the exchange of information, opinions and knowledge". Nonetheless, this dictionary does not record the popular understanding of the concept of social media defined in terms of 'social services, instant messengers and communicators, or social networking portals.' This latter meaning is activated when users of everyday Polish ask, for example: Are you on social media? This latter understanding, not included in the previous explanations, is a manifestation of a popular perspective.

While formulating the research problem developed in this article, I have taken a colloquial perspective. Whenever I write about social media, I mean social networking services and websites, instant messengers and communicators. This is because they have the greatest impact on online communication practices and, consequently, on "offline" (non-Internet-based) communication patterns.

\footnotetext{
${ }^{1}$ This definition is my direct translation into English of the entry media społecznościowe of the Polish version of Wikipedia. The content of the English version differs significantly. The use of the Polish version is justified by the research purpose set out by the author.
} 


\subsection{Selecting the analytical material}

The space limits of this study prevent a comprehensive discussion of the problem of linguistic politeness in Polish social media. The subject matter of the analysis is narrowed down to one particular service so as to delimit our explorations to the standard size format of a research article. In order to minimize the risk of research error, I have chosen Facebook to be the source of my research material, owing to its status as the most popular social networking site in Poland. The high level of popularity of the service is illustrated by the infographics shown in Figure 1 below.

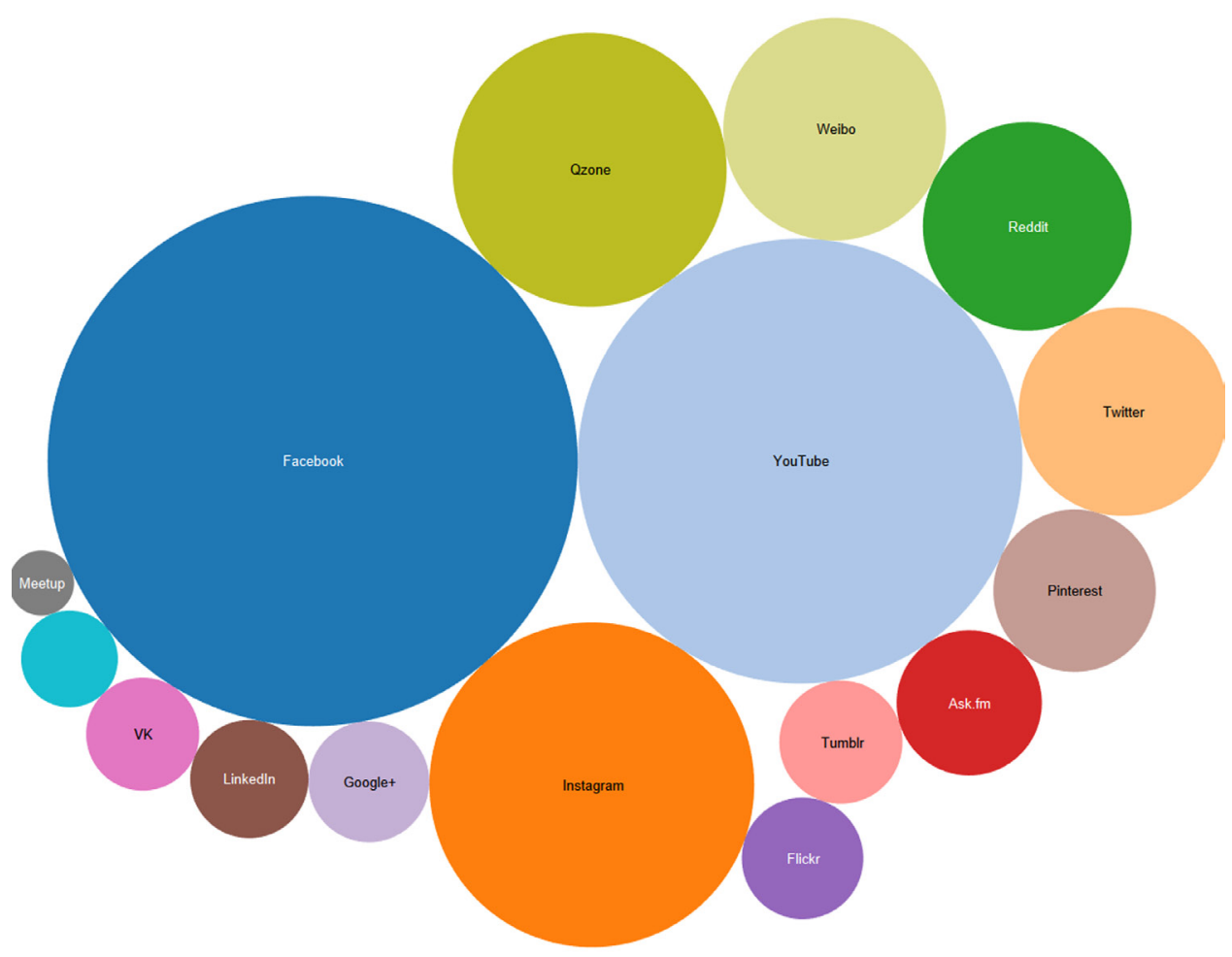

Fig. 1. Popularity of the particular social media services in Poland, May $2018^{2}$.

Source: https://socialpress.pl/2018/06/15-najpopularniejszych-portali-spolecznosciowych-na-swiecie [March 25, 2019].

\footnotetext{
${ }^{2}$ The ongoing popularity of Facebook in the Polish communicative space is confirmed by comparative research conducted in May 2018 (see: dreamgrow.com - https://socialpress.pl/2018/06/15-najpopularniejszychportali-spolecznosciowych-na-swiecie [May 20, 2021]), then in the early 2020 (see: Hootsuite - Media społecznościowe. Które wybierają Polacy? - Money.pl [May 20, 2021]), and finally in January 2021 (see: Hootsuite - Social Media w Polsce 2021 - new repors | Empemedia [May 20, 2021]).
} 


\subsection{Linguistic politeness}

The expression linguistic politeness as used in this article is treated as synonymous with language etiquette. In doing so, I am following the guidelines set in Polish linguistics by Małgorzata Marcjanik3. This linguist defines linguistic politeness (etiquette) as "[1]inguistic and/or non-linguistic behaviour which is inappropriate to abandon in a given conversational situation" $(2007,8)$; a collection of "linguistic politeness patterns adopted in a given community, customarily assigned to specific pragmatic situations" $(2007,12)^{4}$.

Such an understanding of linguistic politeness allows Marcjanik to explore the linguistic behaviour patterns that make up linguistic politeness. First of all, this language resource consists of the so-called politeness expressions and politeness speech acts genres (along with the accompanying or substitutive meta- or non-linguistic behaviours (cf. Marcjanik $2007,14)$. However, the resource also comprises "the choice of the stylistic variant of the linguistic expression" (Marcjanik 2007, 18)). Secondly, and relatedly, the scope of the notion of linguistic politeness also covers the question of the pragmatic appropriateness of politeness behaviours. One of the patterns of politeness linguistic behaviours are expressions that observe the principle of communicative cooperation and respect the expected attitude of the sender towards the recipient (cf. Marcjanik 2007, 19) (e.g. in the version described by Paul Grice (1980) and Geoffrey Leech (1983)) .

In this case, politeness is understood as "a kind of rational cooperation between the communication partners" (Marcjanik 2007, 20). Thirdly, according to Marcjanik, the range of linguistic behaviour patterns that constitute linguistic politeness includes non-linguistic principles: socio-communicative (such as: the principle of "symmetry of behaviour", "solidarity with the partner", or "subordination". This latter principle is further detailed by the sub-principles of "diminishing one's own value", "diminishing one's own merits", or “underestimating one's partner's misconduct" (Marcjanik 2007, 21)). The non-linguistic principles also cover cultural norms (so-called cultural scripts: e.g. "Polish/male politeness towards women", "Polish hospitality", "orientation on sincerity of conversations", that is communicative warmth, confiding in one another) (Marcjanik 2007, 22-26). Here, politeness is understood as a manifestation of communication and cultural competence ${ }^{6}$.

\footnotetext{
${ }^{3}$ The concepts grzeczność językowa (linguistic politeness) and etykieta językowa (language etiquette) are typically used in Polish research publications as synonyms. A need to distinguish between the categories is pointed out by e.g. Kazimierz Sikora $(2010,10)$.

${ }^{4}$ Marcjanik is extraordinarily consistent in her understanding of linguistic politeness. She made use of the term in her article W kręgu grzeczności (Marcjanik 2001a), and later in: Marcjanik 2015/2016.

${ }^{5}$ In her overview of linguistic politeness theories, Anna Żurek (2008, 33-41) observed the politeness-based context of Grice's model of communicative cooperation. She also noted how politeness influenced the politeness principle by Robin Lakoff and the politeness maxims by Geoffrey N. Leech, along with politeness models by Penelope Brown, Stephen Levinson and The Scollons. These can be complemented with the Polish theories of linguistic politeness by Kazimierz Ożóg and Małgorzata Marcjanik.

${ }^{6}$ This broad understanding of linguistic politeness is consistent with the notion of language culture in contemporary Polish linguistics. If we assume that linguistic politeness is a common part of two components of
} 
When presenting the outline of the problem of linguistic politeness in Polish social media, I will take into account all the behavioural patterns identified by Marcjanik as constitutive of linguistic politeness.

\section{LINGUISTIC POLITENESS IN POLISH SOCIAL MEDIAAS AN ISSUE IN MEDIA LINGUISTICS}

The beginning of research on the issue of linguistic politeness in Polish academic circles dates back to the 1990s (cf. primarily: Marcjanik 1990, 1993a, 1993b; Ożóg 1990; Anusiewicz and Marcjanik 1992; Grybosiowa 1998). In some studies, the issue of linguistic politeness is approached in a broad sense, i.e. taking into account the pragmatic principles of conversation (cf. e.g.: Kita 2005; Marcjanik 2007). An important part of these studies is constituted by the analysis of changes taking place in language etiquette (cf. e.g.: Grybosiowa 1998, 2002, 2006; Marcjanik 2001b, 2008). Initially, these changes were triggered by the democratic shift in Polish society after 1989. Later on, the changes resulted from the Internetisation of interpersonal contacts. Already in 2001, Kazimierz Ożóg observed a novel politeness convention: the so-called computer politeness (or "politeness of consumer culture"). It is defined by its departure from the principles of the traditional model of linguistic politeness and replacing the manifestation of kindness towards the interlocutor with focusing on the ego of the message sender (Ożóg 2001, 80-84).

A number of studies have been devoted to the issue of linguistic politeness in Internet communication (especially in e-mail exchanges). Some of them are written from a "positive" perspective (indicating the norms that should be respected as regulatory in online communication - cf. e.g. Budzik 2009; Naruszewicz-Duchlińska 2009, 2011, 2019; Karwatowska and Jarosz 2013). Another group of works represents a "negative" perspective (indicating deviations from the norms of linguistic politeness that govern offline communication - cf. e.g. Dąbrowska 2006; Wojtak 2007; Norwa 2014). The "negative" perspective is often correlated with the normative approach, while the "positive" perspective is usually descriptive. Media linguists quickly made a basic observation that the emergence of social media was a catalyst for the changes in contemporary Polish language because they displayed features that no other media could offer (cf. Gajda 2010; Grzenia 2006, 2008; Skowronek 2019). These observations can be supplemented with the results of our analyses of linguistic politeness behaviours observed in social media.

\section{RESEARCH METHODOLOGY FOR LINGUISTIC POLITENESS IN SOCIAL MEDIA}

The research procedure applied in this article consists of three stages. They are a consequence of adopting a broad understanding of linguistic politeness (along the lines

language culture - the aesthetics of verbal expression and the ethics of verbal behaviour - the paramount postulate of linguistic politeness is to respect the habits of the addressee and to adapt to his expectations. I would like to stress that in Russian linguistics, too, an analogous, broad understanding of linguistic politeness is adopted. Such a broad understanding of linguistic politeness is particularly valued by media linguists (Duskaeva 2018, 235-238). 
developed by Marcjanik). The procedure rests on an assumption that three types of language data need to be included in the inventory of linguistic politeness behaviour patterns: formal-stylistic, pragmatic (reaching out beyond the stylistic data) and socio-cultural.

- Stage I consists of examining the selected text material for the occurrence of so-called politeness expressions and politeness speech acts. Also researched are meta- and non-linguistic behaviours (accompanying or replacing the former, or being their substitute) as well as the stylistic structure of the analysed utterances.

- Stage II consists of examining the compliance of the analysed utterances with the principle of communicative cooperation (individual maxims constituting this principle) $)^{7}$.

- Stage III consists of examining the conformity of the analysed utterances with non-linguistic, communicative, psychological and cultural norms.

Carrying out my analysis of linguistic politeness in social media in its three-stage procedure, I rely on methods of qualitative and quantitative analysis in their typical formulation for media linguistics.

\section{RESEARCH MATERIAL ANALYSIS}

The direct object of my analysis is the forum discussion conducted on 11-12 March 2019 on one of the Facebook pages on the local "Spotted Lublin" website. The discussion was triggered by the following post:

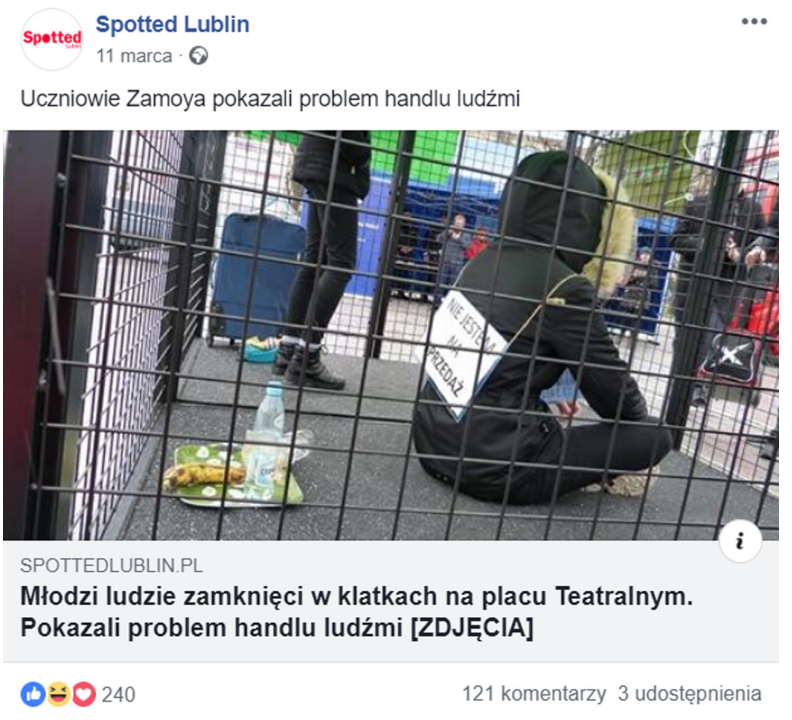

\footnotetext{
${ }^{7}$ This stage is further elaborated in the article by Alena Podviazkina Polilog $w$ mediach spotecznościowych - tematyczna struktura tekstu a grzeczność językowa (2020).
} 
This post referred to a happening organised by the students of the Secondary School No. 2 in Lublin (LO II). The school's patron is a Polish nobleman, Hetman Jan Zamoyski, and hence the school is often unofficially referred to as Zamoy. The choice of the object of analysis is not random. The first parameter that determined the choice was the local character of the subject matter and, consequently, they possess knowledge of the extra-linguistic reality in which the discussion is taking place. Secondly - and more importantly - the fact that the forum of the Spotted Lublin group is a typical example of a Facebook group forum: it has a polylogous (multiaccess and multiuser) and an asynchronous character. It constitutes an example of "oral (secondary) literacy"; participation is not equally accessible to all language users, either because of technical constraints or because of the difficulty in decoding conversations owing to the particular language form they take. This text form is characterised by formal abbreviation, spelling modifications, the use of non-verbal code (e.g. emoticons), the use of sociolectal vocabulary, hypertext and multimodality, as well as by the "multidirectionality of conversation" (cf. Karwatowska and Jarosz 2016, 234-240).

The framework for the discussion is shaped by the technical capabilities of Facebook. The analysed forum allows users to make first-, second- and third-level comments. I treat these comments as dialogue phrases. These phrases are autonomous utterances taking verbal or non-verbal form. The first- and second-level comments that make up the discussion are numbered. Written in square brackets, the numbers indicate the position of a given comment in the structure of the discussion. The phrases in the first level have numbers from [1] to [52], and the phrases in the second level - i.e. those referring to the individual comments to the first level - have numbers indicating the relevant number of the commented phrase in the first level, and the number of the relevant comment of the second level, e.g. [1.1.], [1.2.], [3.1.], [3.2.]. Facebook's technical capabilities determine the nature of level-three comments, i.e. the reactions of group members to level-two comments. These are usually emoticons: autonomous iconic messages marking response patterns that a user can pick from a limited list provided by Facebook: - "like it" - - "super" - "ha ha" - "wow" - "sorry" - ,wrr". These responses are recorded in terms of the number of occurrences, yet without indicating the authors of the particular responses. Even though the emoticons have not been written down as dialogue phrases, I treat them as such because they function as a voice in the discussion. It should be noted that the analysed first-level comments do not take the form of autonomous iconic messages, and the second-level comments are a hybrid type. In total, the analysed discussion consists of 442 dialogue phrases: 52 first level comments, 390 second-level comments (including 65 verbal or verbaliconic comments and 325 autonomous iconic messages) and 94 third-level comments (only autonomous iconic messages). 


\subsection{Analysis - Stage I}

In Stage I of the analysis, the discussion of the Spotted Lublin group was examined for the occurrence of politeness phrases, politeness speech acts genres, as well as the choice of their stylistic variants.

\subsubsection{Politeness phrases}

In the analysed posts, there are no conventional expressions of politeness. For this reason, the addressing function is performed differently, both traditionally and non-traditionally. The traditional address is implemented by using:

- personal proper names (6 instances in 117 dialogue phrases in the first and the second level containing a verbal message):

\section{Polish script:}

[3.67.] [Ania P.]: Kalina C. nigdzie.

[3.68.] [Kalina C.]: Anna P-o no piszo przeca, że za tyle nerki chodzo! Dejcie namiary a nie sami tylko zgarniacie :(

[3.69.] [Iga O.]: Kalina jak się dowiesz toooo w kontakcie!

[4.80.] [Patryk G.]: Kamil Koper na czarnym rynku w usa wg internetu za 262k dolarów można kupić. Czyli x 3.8 wychodzi $955 \mathrm{k}$ zł

[4.81.] [Cezary S.]: Patryk Gnyś w Indiach itp sprzedaja po okolo 10-20 tys

[51.2.] [Adrian K.]: Pafku dla mnie to nie problem, Dla mnie to biznes

\section{English version (for illustration purposes only):}

[3.67.] [Ania P.]: Kalina C. nowhere.

[3.68.] [Kalina C.]: Anna P-o, they say that kidneys cost a lot of dough! Give us contact info, don't just suck up all the money yourselves :(

[3.69.] [Iga O.]: Kalina Kalina, when you find out, let us know!

[4.80.] [Patryk G.]: Kamil Koper you can read online that on the US black market they go for for \$262k. Times x3.8 - makes 955k PLN

[4.81.] [Cezary S.]: Patryk Gnyś in countries like India they sell for about 10-20k

[51.2.] [Adrian K.]: Pafku it's not a problem for me, it's business

- personal pronouns ty, wy, my [you sing. and pl., we ] (14 instances in 117 dialogue phrases containing verbal message) or verbs in 2 nd. person singular or plural and 1st. person plural (17 instances in 117 first- and second-level dialogue phrases containing verbal message): 


\section{Polish script:}

[3.68.] [Kalina C.]: M Anna P-o no piszo przeca, że za tyle nerki chodzo! Dejcie namiary a nie sami tylko zgarniacie :(

[3.72.] [Agnieszka N.]: I ja ze 3 sztuki opchnę. Gleń Ty to się wątroby pozbądź przy okazji co? :D

[7.8.] [Jasiek.B.]: no ty dobrze że dużo robileś

[8.] [Rafał P.]: Jakub G. w klatce cię zamkną jak tam pójdziesz

[9.] [Damian D.]:Natalia F. ciebie tez zamknąć?

[14.4.] [Patryk T.]: Michał W. i tak wiem, że jesteś za to odpowiedzialny XDD

[15.] [Stanisław W.]: Natalia niezle sie bawisz

[18.] [Bartek C.]: Kacper P. to dlatego wczoraj nie mogles wystarczyło powiedzieć ze idziesz dac się zamknąć w klatce

[19.] [Nikolas D.]: Natalia za ile wycenilas Ania XD

[19.3.] [Ania K.]: Z moimi talentami to już nie oszkukuj. Wiem że nie cgesz się przyznać do tych milionów [22.] [Iga O.]: Julia nikt cię w koncu nie kupił?

[26.2.] [Michał C.]: po tych wszystkich dwu złotowych napojach energetycznych wypitych przez ciebie moge dać 3 zł za nerke

[26.7.] [Michał C.]: patrzyłeś kiedykolwiek na skład 2 złotowego energetyka ? tam to alko to pikuś

[26.10.] [Dawid G]: Michał C. albo jak nasz ukochany Lazorczyk:

DWA RAZY WAS PRZEWIEJE TAM I WAS NIE MA

[27.] [Damian B.]: Bartosz S. co ty wyczyniasz

[27.1.] [Bartosz S.]: Damian B. To Ty mnie chcialeś za 5zl na targu sprzedać bo Ci ma flaszkę brakowało

[28.] [Arek W.]: Mikołaj D. dlaczego wszędzie gdzie widzę Zamoj to mi sie zawsze przypomina wasz śmietnik?

[31.] [Radek S.] Kuba opylamy po jednej nerce i przestajemy być dziadami finansowymi

[47.1.] [Jakub J.]: chcesz zostac moim niewolnikiem?

[47.2.] [Wiktoria S.]: bede zebrać dla cb

[51.4.] [Adrian K.]: Pomyśl sobie nad takim biednym milionerem który ma raka płuc,

Dla takiego jedynym ratunkiem jest przeszczep.

\#niebujmysiepomagac

\section{English version:}

[3.68.] [Kalina C.]: Anna P-o, they say that kidneys cost a lot of dough! Give us contact info, don't just suck up all the money yourselves :( 
[3.72.] [Agnieszka N.]: I can also sell three. Gleń, why don't you get rid of your liver, by the way? :D

[7.8.] [Jasiek.B.]: Well, it's good that you did a lot

[8.] [Rafał P.]: Jakub G., they will lock you in a cage if you go there.

[9.] [Damian D.]: Natalia F., you also want to get locked?

[14.4.] [Patryk T.]: Michał W., I know you're the one responsible for this XDD

[15.] [Stanisław W.]: Natalia, seems you're having fun

[18.] [Bartek C.]: Kacper P., that's why you couldn't do it yesterday. You could just say you were going to get locked up in a cage.

[19.] [Nikolas D.]: Natalia, so how much do you pay for Ania's XD

[19.3.] [Ania K.]: With my talents you won't cheat me. I know you don't want to admit to having all those millions

[22.] [Iga O.]: Julia, nobody bought you in the end?

[26.2.] [Michał C.]: After all these cheap energy drinks you've gobbled, I can give three PLN for your kidney.

[26.7.] [Michał C.]: Have you ever checked the ingredients these cheap energy drinks? Alcohol is not a problem at all if you compare.

[26.10.] [Dawid G]: Michał C., or like our beloved Łazorczyk: YOU CATCH A CHILL TWICE AND YOU'RE GONE.

[27.] [Damian B.]: Bartosz S. what are you doing?

[27.1.] [Bartosz S.]: Damian B. You were the one who wanted to sell me for 5 PLN at the market cause you were short bucks to buy booze

[28.] [Arek W.]: Mikołaj D., why everywhere I see can Zamoy, it reminds me of all this old mess of yours

[31.] [Radek S.] Kuba, let's sell one kidney each and we are beggars no longer.

[47.1.] [Jakub J.]: Want to be my slave?

[47.2.] [Wiktoria S.]: I'll beg for you $\mathbf{u}$ ?

[51.4.] [Adrian K.]: Think of all those poor millionaires with lung cancer, who can only be saved by a transplant. \#notafraidtohelp

The non-traditional addressing is dependent on the technical capabilities of social media: it is a username entered by the addressee in the category 'name and surname' in the appropriate form to be filled in when joining Facebook groups 8 . (Of course, the name does not have to be the real name of the person joining the group). This form of address may also be realised by a name given to a particular member of the group in the Facebook comment form by the comment sender. Significantly, these names (marked

\footnotetext{
${ }^{8}$ Owing to the GDPR constraints, the names of group members in the examples are abbreviated.
} 
graphically in bold font) play the role of activation links: they are a technical way to "call" a specific person, because the message with the hyperlink to a given addressee reaches him/her in the form of a notification. Thus, the sender may direct his/her message to any of the registered members of the group, whereas the addressee is not required to pick up the message from the flood of the multi-threaded discussion. Thanks to the activation links, usernames function similarly to mailing addresses in traditional paper mail: they take the nominative case and they are used to ensure an appropriate delivery of the message to the addressee. This way of addressing is used in the analysed discussion 51 times in 117 verbal dialogue phrases in the first and second level containing verbal messages. Due to the graphical clarity of this way of addressing (activation links are highlighted in blue font), I will only mention a few examples by way of illustration:

\section{Polish script:}

[3.71.] [Mateusz K.G.]: Kalina C. jak coś ja też

[3.73.] [Mateusz K.G.]: Agnieszka N. czego ? XD

[5.] [Mateusz W.]: Natalia XD

[5.7.] [Jan P.]: Natalia F.

[7.] [Mateusz.T.]: Jasiek Hubert Kuba feeejm

[7.4.] [Jasiek.B.]: Mateusz T. byłem tak

[16.] [Anna W.]: Sprzedam nerkę Pauliny F. priv

[19.] [Nikolas D.]: Natalia za ile wyceniłas Ania XD

[25.] [Wojtek D.]: Brawo Natalka jestem dumny!

[46.] [Gabriela S.]: Wiktoria Wiktoria Kaja Zuzanna

\section{English version:}

[3.71.] [Mateusz K.G.]: Kalina C., I'm in if you ask me.

[3.73.] [Mateusz K.G.]: / Agnieszka N., what? XD

[5.] [Mateusz W.]: Natalia XD

[5.7.] [Jan P.]: Natalia F.

[7.] [Mateusz.T.]: Jasiek Hubert Kuba, faaaame

[7.4.] [Jasiek.B.]: Mateusz T., yes, I was there

[16.] [Anna W.]: Paulina F.'s kidney is up for sale, priv

[19.] [Nikolas D.]: Natalia, so how much do you pay for Ania's XD

[25.] [Wojtek D.]: Good job, Natalka I'm proud of you!

[46.] [Gabriela S.]: Wiktoria Wiktoria Kaja Zuzanna 
Activation links are more frequent in phrase initial positions (see e.g. [3.71.], [3.73.], [5.]) than in the middle (e.g. [16.], [19.], [25.]). They are separate acts of address (e.g. [46.], [3.71.], [3.73.], [7.]) or they make part of informative, appellative or evaluative acts (cf. e.g. [16.], [19.], [25.]).

Addressing techniques on Facebook may have been one of the factors influencing the choice of the nominative form of the personal names, as used in traditional mailing addresses. Out of the 6 manifestations of this way of address, 5 took the nominative case (Kalina C., Anna P-o, Kalina, Kamil Koper, Patryk Gnyś). Only one name was put in the vocative $(P a f k u)$. It cannot be ruled out that the proportions between the vocative and the nominative case are indicative of a more general communicative trend which witnesses users' abandonment of the vocative form. In the context of our study of linguistic politeness, the dominance of the nominative form (traditionally considered a less accurate form of address than the vocative) may be interpreted as a violation of the principles of traditionally understood linguistic politeness or as a manifestation of linguistic politeness patterns applicable in Polish social media.

\subsubsection{Politeness speech act genres}

I define politeness speech act genres as forms of:

greeting, [...] introducing oneself and introducing someone to someone else, wishes, congratulations, sympathy, offering, invitations, declarations of help, compliments and praise, moving to "you" as a form of address (familiarization), toasts, thanks, apologies and goodbyes. (Marcjanik 2007, 7).

I assume that these politeness speech acts can be carried out using verbal and nonverbal means.

The analysed material includes realisations of three politeness speech act genres: greeting, compliment/praise, and gratitude. The frequency of greetings is difficult to determine because the form they take in the discussion forum Spotted Lublin is not traditional. One can presume that the greeting function is performed by some of the acts of address (cf. paragraph 4.1.1. of this article), but it is difficult to determine precisely which of them do. The gratitude speech act genre is different. The sole formal realisation of gratitude - [51.8.] [Janek M.]: Dzięki $:$, [Eng. Thanks $\dot{*}^{*}$, ] - is a conventional, syncretic, verbal-visual message. However, it does not represent a politeness speech act genre. In fact it constitutes an easily decodable ironic response to the preceding ironic post: [51.7.] ([Adrian K.]: I właśnie takich dawców potrzebujemy // Nie palacy, nie pijacy zloto nie czlowiek [Eng. [51.7.] [Adrian K.]: And that's the kind of donors we need // (He/she) Doesn't smoke, doesn't drink - pure gold.]). It may well be the case that some of the applications of positive emoticons represent a form of gratitude. In the case of iconic messages, however, it is difficult to distinguish decisively between "thank you" and "appreciation" - the latter being a case of the "compliment/praise" genre.

The "complement/praise" genre predominantly takes the form of positive emoticons: (1) - „like it”; 0 - „super”; - ,wow”. However, in the case of these iconic 
messages, it is difficult (from the perspective of an average forum member) to determine which of these represent direct acts and which represent indirect ones. The abundance of such messages clearly exceeds the number of verbal realisations of the compliment/ praise genre. In the whole discussion (at the second and third levels), only 5 verbally realised "compliments/praises" can be found, while there are as many as 325 autonomous iconic messages that can be regarded as the implementation of the "compliment/ praise" genre $(2910 ; 240 ; 10 \%$ ). What is more, three realisations of the genre have an obvious ironic overtone; hence, they cannot be treated as actual representatives of a politeness speech act genre:

\section{Polish script:}

[7.8.] [Jasiek. B.] no ty dobrze że dużo robiteś; [39.] [Krzysiek P.] No normalnie bohaterzy..... Przyszłość intelektualna polskiego narodu......; [51.7.] [Adrian K.] I właśnie takich dawców potrzebujemy // Nie palacy, nie pijacy złoto nie człowiek).

\section{English version:}

[7.8.] [Jasiek. B.] Well, it's good you did a lot; [39.] [Krzysiek P.] Real heroes..... The intellectual capital for the future of the Polish nation......; [51.7.] ([Adrian K.]: And that's the kind of donors we need // (He/she) Doesn't smoke, doesn't drink - pure gold.

Taking into account the context, only two statements can be regarded as examples of compliment/praise: [25.] [Wojtek D.] Brawo Natalka jestem dumny!; [47.3.] [Jakub J.] oo fajnie, fajnie [Eng. [25.] [Wojtek D.] Good job, Natalka I'm proud of you!; [47.3.] [Jakub J.] / oh, that's cool, really].

\subsubsection{The stylistic form of the politeness expressions}

Social media stylistics are characterised by colloquialism (manifested at all but one phonetic level of language), abbreviation of forms, and familiarity of address. The forum discussion analysed in this article is a clear example of these properties. Colloquialism results primarily from the use of certain lexical units (cf. e.g. opchnać). At the grammatical level, colloquialism manifests itself - among other ways - through the communicative practice discussed in paragraph 4.1.1. of using the nominative instead of the vocative form of address.

Another illustrative case is the use of abbreviations - conventional or innovative which are in standard use both in offline communication (e.g. Zamoy, $m \ln , u s a, w g$, itp, tys) and in online contexts (e.g. priv). The abbreviation of forms is also reflected in a specific syntactic organisation of the utterances (e.g. through the use of verbless clauses): [3.69.] [Iga O.]: Kalina jak się dowiesz toooo w kontakcie! [Eng. Kalina, we are in touch if you get to know]; also in the abandonment of the question word: [26.7.] [Michał C.] patrzyłeś kiedykolwiek na skład 2 złotowego energetyka ?; [Eng. Have you ever checked the ingredients in these cheap energy drinks?] as well as in the most 
frequent and most noticeable type of formal abbreviation by means of iconic signs (e.g. so-called emoticons). The familiarity associated with colloquialism can be illustrated by the following examples:

\section{Polish script:}

[27.] [Damian B.]: Bartosz S. co ty wyczyniasz; [27.1.] [Bartosz S.]: Damian B. To Ty mnie chciałeś za $5 z$ na targu sprzedać bo Ci ma flaszkę brakowato ; [50.1.] [Gabriela K.]: to nie ja taka maniane odwalam.

\section{English version:}

[27.] [Damian B.]: Bartosz S. what do you think you are doing? [27.1.] [Bartosz S.]: Damian B. You were the one who wanted to sell me for 5 PLN at the market cause you were short bucks to buy booze [50.1.] [Gabriela K.]: It's not me who is freaking out.

When analysing the stylistic aspect of Polish social media communication, I cannot ignore a case of old Polish stylisation that I have noticed in the discussion: [3.68.] [Kalina C.]: M Anna P-o no piszo przeca, że za tyle nerki chodzo! Dejcie namiary a nie sami tylko zgarniacie:( [Eng. Anno P-o, they say that kidneys cost a lot of dough! Give us contact info, don't just suck up all the money yourselves :(]. It violates the stylistic norm of a statement made in public through the media. As a result, the violation contributes to a new idiolectal style that serves the realisation of an expressive intention motivated by colloquialism.

\subsection{Analysis - Stage II. Researching compliance with conversational maxims}

In Stage II of the analysis, the discussion in the Spotted Lublin group was examined for the degree of compliance of the analysed utterances with the particular maxims fulfilling the principle of communicative cooperation (cooperative principle). This stage of the analytical procedure is a corollary of the broad understanding of linguistic politeness we adopt. Using the cooperative principle as a method of verification of the properties of a social media language etiquette results from our thinking about language etiquette as a way of manifesting the desired relationship between the sender and the recipient, as well as of acting in accordance with the recipient's expectations. In the case at hand, this means that speaking and behaving is in line with the particular maxims of communicative cooperation.

A detailed analysis of the issue of thematic coherence of the forum discussion is outlined in the article by Alena Podviazkina (2020). This analysis confirms, first of all, the correctness of the claim that the forum discussion constitutes a "multi-directional thematic conversation" (cf. Karwatowska and Jarosz 2016, 234-240). Podviazkina demonstrates that the structure of the Spotted Lublin discussion has an associative character. The principle of thematic coherence applies only at the level of individual threads (subthemes) of this discussion. Secondly, Podviazkina's analysis shows that the starting 
point of the discussion (the "happening involving students from LO II in Lublin") is not a hypertheme, i.e. it does not bind the analysed communication universe together. The initial topic is a pretext for the sender to talk about himself/herself. Therefore, one can say that the topic of most of the dialogue phrases, i.e. the hypertheme that makes the discussion more coherent, is, in this case "talking about oneself". The manifestation of the sender's "I" has a number of realisations. The sender not only directly writes about himself/herself, or expresses his or her assessment of reality (physical or mental). Diverse language games used by users to show themselves as intelligent and witty are also a form of expression (cf. e.g. Kępa-Figura 2009). One of the types of language games are conversation games based on breaking particular conversation maxims (cf. e.g. Kępa-Figura 2011).

It is important to note that the discussion on the forum treats both the associative thematic structure and the specific self-thematic orientation in terms of the norms, including the politeness norms.

Examining the discussion in the Spotted Lublin Facebook group for respecting the maxims of reference, method, quantity and quality, shows that the basic form of expression in the forum is the indirect communicative act. Acts of this kind rely on breaking individual maxims in order to initiate the inference of the implied content. The difference between traditional and social media communication is mainly quantitative. In the analysed discussion, direct speech acts constituted a minority. The latter can be exemplified by the following phrases:

\section{Polish script:}

[1.96.] [Stanisław S.]: Chodzi o uświadamianie młodych ludzi o istniejącym zagrożeniu; [1.97.] [Dawid J.]: Nic lepiej na młodych ludzi nie działa niż takie coś, serio na pojawiło się jedynie.

\section{English version:}

[1.96.] [Stanisław S.]: It's about making young people aware of the real risk; [1.97.] [Dawid J.]: Nothing has a greater impact of youth than this, seriously, just one look.

I would like to point out that the ironic, multimodal statements made on the forum using the technical capabilities available to the users of an online forum - ones that in traditional communication could be considered incompatible with individual maxims are accepted by the users.

\subsection{Analysis - Stage III. Researching compliance with extra-linguistic norms}

By including extra-linguistic principles within the inventory of linguistic politeness norms, I have tried to assess the compliance of the Spotted Lublin group's discussions with the communication, psychological and cultural principles holding for traditional modes of communication. Moreover, I have tried to identify the extra-linguistic principles constituting the linguistic politeness inventory characteristic of Polish social media (as defined above). 
Exploring the communicative and psychological norms of the traditional model of Polish linguistic politeness, Marcjanik elucidated the principles of "symmetry of behaviour", "solidarity with the partner", and "taking the subordinate role (subordination)". In the Facebook discussion under analysis, the last of the above-mentioned rules does not apply. It is replaced by what I call the principle of communicative equality. However, the first of the principles advocated by Marcjanik - the principle of symmetry of behaviour - is consistently respected. It is reflected in the practice of users reacting to phrases addressed to them, as well as in the harmony of stylistic means used in the particular phrases in the dialogue. Whatever the form of the addressing act (see paragraph 4.1.1.), it usually results in a comment from the addressee. This comment takes a verbal or an iconic form. Thus, four types of behaviour that testify to the symmetry of communication can be distinguished:

- verbal response to traditionally addressed utterances

- iconic response to traditionally addressed utterances

- verbal response to non-traditional addressed utterances

- $\quad$ iconic response to non-traditional addressed utterances

Out of these four types of behaviour, only the last two can be verified in the analysed material. Verbal responses to non-traditional addressed statements can be illustrated as follows:

\section{Polish script:}

- [7.] [Mateusz.T.]: Jasiek Hubert Kuba feeejm => [7.4.] [Jasiek.B.]: Mateusz T. bytem tak

- [9.] [Damian D.]: Natalia F. ciebie tez zamknać? => [9.2.] [Natalia F.]: Już mnie zamknęli hahah

\section{English version:}

- [7.] [Mateusz.T.]: Jasiek Hubert Kuba faaaame $=>$ [7.4.] [Jasiek.B.]: Mateusz T., I was there

- [9.] [Damian D.]: Natalia F., want to get locked, too? => [9.2.] [Natalia F.]: I got locked already, hahah.

On the other hand, the following cases illustrate iconic responses to non-traditional addressed utterances:

\section{Polish script:}

- [5.] [Mateusz W.]: Natalia $X D \Rightarrow>$ [5.1.] [Natalia]

- [2.] [Filip G.]: Pawet K. przegapiliśmy

\section{English version:}

- [5.] [Mateusz W.]: Natalia $X D=>$ [5.1.] [Natalia]

- [2.] [Filip G.]: Pawet K. Lost our chance 
Lack of response to traditionally addressed utterances is a sign of its low effectiveness.

The second of the above-mentioned communication and psychological principles the principle of "solidarity with the partner" - is respected (although often in a very specific way). This principle is realised when both interlocutors display consistency of views. A specific manifestation of adhering to this principle is the use of many positive, accepting emoticons. Hence, the principle of "solidarity with the partner" should be recognised as an important indicator of politeness in social media. At the same time, it is important to keep in mind that, for a similar reason, the use of negative emoticons can be seen as a violation of this principle.

Compliance with the principle of "solidarity with the partner" can also be expressed verbally. Obvious manifestations of this principle are serious statements and direct speech acts:

\section{Polish script:}

[1.] [Dawid J.]: Bohaterzy, dzięki nim przestana handlować. Odkryli jeden prosty trik jak pozbyć się handlu ludźmi. Zobacz jak --->

[1.96.] [Stanisław S.]: Chodzi o uświadamianie młodych ludzi o istniejacym zagrożeniu

[1.97.] [Dawid J.]: Nic lepiej na młodych ludzi nie działa niż takie coś, serio

\section{English version:}

[Dawid J.]: Heroes: they will put an end to the problem. They discovered one simple trick how to get rid of human trafficking. See how --->

[1.96.] [Stanisław S.]: It's about making young people aware of the real risk;

[1.97.] [Dawid J.]: Nothing has a greater impact of youth than this, seriously, just one look.

Similarly, ironic statements are obvious manifestations of the suspension of the principle of solidarity. (e.g.: [39.] [Krzysiek P.]: No normalnie bohaterzy..... Przyszłość intelektualna polskiego narodu......). [Eng. [39.] [Krzysiek P.] Real heroes..... The intellectual capital for the future of the Polish nation......].

Significantly, statements of this kind are frequently expressions of solidarity with partners in social media:

\section{Polish script:}

[26.] [Dawid G]: Nerke mam do sprzedania // Lat 16 nowiutka

[26.2.] [Michał C.]: po tych wszystkich $d$ wu złotowych napojach energetycznych wypitych przez ciebie moge dać 3 zt za nerke 


\section{English script:}

[26.] [Dawid G]: I have a kidney for sale // 16 years old, brand new

[26.2.] [Michał C.] After all these cheap energy drinks you've gobbled, I can give three PLN for a kidney

In this case, solidarity with the partner is linked to the cultural principles applicable in social media. The principle can develop into a relationship that I would like to call the principle of communication distance.

Of the two cultural principles recognised by Marcjanik as distinctive features of the traditional model of Polish linguistic politeness - "Polish/male politeness towards women" and "attitude towards sincerity of conversation" - only the second one is respected in the analysed material. However, the principle does not take on its traditional form, i.e. the form of confiding that ensures the effect of communicative warmth. Instead, it adopts the form of exchange based on breaking various types of norms, including the rules of linguistic correctness, as well as linguistic and extra-linguistic appropriateness:

\section{Polish script:}

[14.] [Patryk T.]: Michat Barttomiej co to ma być do jasnej ciasnej? $\because$;

[22.3.] [Julia G.]: Iga O. ja sprzedawatam $=/ /$ [22.4.] [Daniel W.]: Julia G. się

[26.6.] [Dawid G]: Wydajność to w większości alko chyba rozdupca

[26.7.] [Michał C.]: patrzyteś kiedykolwiek na sklad 2 złotowego energetyka ? tam to alko to pikuś

\section{English version:}

[14.] [Patryk T.]: Michat Barttomiej, what the hell is this?

[22.3.] [Julia G.]: Iga O. I sold this $\because / /$ [22.4.] [Daniel W.]: Julia G. herself

[26.6.] [Dawid G]: Performance is mostly screwed up by alcohol, I guess.

[26.7] [Michał C.]: Have you ever checked the ingredients these cheap energy drinks? Alcohol is not a problem at all if you compare.

The basis for this specific familiarisation of message is the ludic element. In the model of linguistic politeness in social media, this ludic overtone takes the form of a ridiculing, mocking attitude towards reality, which can be treated as a cultural principle characteristic of social media:

\section{Polish script:}

[35.] [Ola G.]: Lublin stanem umyslu po raz kolejny. Problemy nie istnieja hihi sprzedam nerke

[39.] [Krzysiek P.]: No normalnie bohaterzy..... Przyszłość intelektualna polskiego narodu...... 


\section{English version:}

[35.] [Ola G.]: Lublin - a state of mind once again. Problems are not there, hahah, I will sell a kidney

[39.] [Krzysiek P.] Real heroes..... The intellectual capital for the future of the Polish nation......

\section{CONCLUSIONS}

The formulation of conclusions regarding the research problem of linguistic politeness in social media is closely linked to the way of thinking about linguistic politeness as a normative or descriptive category. Thinking of politeness as a normative category is correlated with assessing the conformity of social media practices with the traditional principles of linguistic politeness. The consequence of adopting a normative perspective is a statement that the principles of linguistic politeness are violated in social media. The individual messages on the forum display no compliance with traditional formulations of linguistic politeness. There are almost no traditionally realised politeness speech act genres, and the stylistic forms of the message are distinct from the idea of communication perceived in terms of linguistic politeness. The departure from the principles of language etiquette is also illustrated by the inconsistency of the analysed phrases with the principles of linguistic cooperation and violation of the communicative, psychological as well as cultural principles that apply in traditional communication.

Thinking of linguistic politeness as a descriptive category opens up new interpretative pathways. First of all, it leads to the observation of a multitude of "linguistic politenesses" competing against each other among the speakers of Polish. Individual patterns of linguistic politeness apply within individual language communities - including social media users. By treating the principle of communicative cooperation as a manifestation of the linguistic competence of the members of a particular language community, I associate it with their social, communication and cultural competences. Consequently, I connect these competences with the users' awareness of the qualities and capabilities typical of a given speech act genre (including its norms of linguistic politeness).

With this perspective in mind, I would like to draw the following conclusions regarding linguistic politeness in social media:

- Linguistic politeness in social media is influenced by technical capabilities of conducting verbal exchange.

- The use of direct address phrases is not required. A communication behaviour that replaces traditional addressing is the insertion of hyperlinks that ensure the effective exchange and addressing of utterances. However, these procedures should be regarded not only as manifestations of communicative pragmatism, but also as expressions of linguistic politeness, for their use is advisable and recommended.

- Linguistic politeness implemented through the selection of specific speech act genres has numerous, but formally limited, representations. The dominant 
politeness genre is praise/compliment. It takes the form of conventionalised iconic messages, mainly so-called positive emoticons.

- Linguistic politeness ensures that conversations are conducted in accordance with norms of the official status (register) of the message. A language etiquette norm in social media is that messages need to adapt to the regime of colloquialism, formal abbreviation, and familiarity.

- The commonly accepted, desired communication behaviour is to speak about oneself and formulate indirect speech acts. Verbal and non-verbal messages are considered equivalent expressions of politeness.

- The basic inventory of communication and psychological principles of politeness characteristic in Polish social media includes the principle of symmetry of communication behaviour and the contrasted principles of solidarity with the partner versus that of communication distance. The most important cultural principle of politeness is sincerity of conversation, combined with the previously discussed principles of linguistic politeness regarding the form of expression. The effect of sincere conversation is achieved by breaking various norms, including rules of linguistic correctness and of linguistic and extra-linguistic appropriateness. The principle of a ridiculing attitude towards reality correlates with the latter principle.

The final conclusion of this article is a general observation regarding the essence of the politeness model in social media. It turns out that the differences between traditional and social media linguistic politeness norms are not as profound as one might think on the basis of the different manifestations of these politeness models. Communication in social media is largely based on the same communication script as traditional communication: adapting to the expectations of the recipient.

\section{REFERENCES}

Anusiewicz, J., and M. Marcjanik, red. 1992. Język a Kultura [Language and Culture], vol. 6: Polska etykieta językowa [Polish Language Etiquette]. Wrocław: Wiedza o Kulturze.

Budzik, M. 2009. "Uwagi o kulturze komunikacyjnej w Internecie" ["Remarks on Communication Culture on the Internet"]. In Norma a komunikacja [Norm and Communication], red. M. Steciąg and M. Bugajski. Wrocław: Oficyna Wydawnicza Atut-Wrocławskie Wydawnictwo Oświatowe, 227-238.

Dąbrowska, M. 2006. “(Nie)grzeczność w mediach elektronicznych” [“(Im)politeness in Electronic Media”]. Biuletyn Polskiego Towarzystwa Językoznawczego LXII: 117-127.

Duskaeva, L.R. 2018. "Rečevoj ètiket v massmedia" ["Language Etiquette in Massmedia"]. In Medialingvistika v terminah i ponâtiâh: Slovar'lspravočnik [Media Linguistics in Terms and Concepts: A Glossary], ed. L.R. Duskaeva. Moscow: Flinta, 235-238.

Gajda, S. 2010. "Nowe media w perspektywie lingwistycznej" ["New Media Observed from a Linguistic Perspective"]. In Styl - dyskurs - media [Style - Discourse - Media], red. B. Bogołębska and M. Worsowicz. Łódź: Wydawnictwo Uniwersytetu Łódzkiego, 25-31. 
Grice, P. 1980. "Logika a konwersacja" ["Logic and Conversation”]. In Język w świetle nauki [Language in the Light of Science], red. B. Stanosz. Warszawa: Czytelnik, 91-114.

Grybosiowa, A. 1998. "Przyczyny zmian w polskim systemie adresatywnym" ["Causes of Change in the Polish Forms of Address"]. Acta Universitatis Lodziensis. Folia Linguistica 37 (Język w mieście. Problemy kultury i poprawności [Language in City Spaces: Issues in Culture and Correctness]): 57-61.

Grybosiowa, A. 2002. "Nowe sytuacje - nowe zachowania grzecznościowe" ["New Situations - New Behvaioural Forms of Politeness"]. Poradnik Językowy 2: 3-8.

Grybosiowa, A. 2006. "Destrukcja tradycyjnego, polskiego modelu grzeczności. Nowe formuły globalne" ["Destruction of the Traditional, Polish Model of Politeness. New Global Formulations"]. In Przemiany języka na tle przemian wspótczesnej kultury [Language Change and Contemporary Cultural Change], red. K. Ożóg and E. Oronowicz-Kida. Rzeszów: Wydawnictwo Uniwersytetu Rzeszowskiego, 31-37.

Grzenia, J. 2006. "Zasady komunikacji internetowej” ["Principles of Internet Communication”]. In Polszczyzna na co dzień [Everyday Polish], red. M. Bańko. Warszawa: Wydawnictwo Naukowe PWN, 311-345.

Grzenia, J. 2008. Komunikacja językowa w Internecie [Langauge Communication on the Internet]. Warszawa: Wydawnictwo Naukowe PWN.

Kaplan, A.M., and M. Haenlein. 2010. "Users of the World, Unite! The Challenges and Opportunities of Social Media”. Business Horizons 53 (1): 59-68.

Karwatowska, M. and B. Jarosz. 2016. "Forum internetowe, czyli (cyber)komunikacja o ograniczonym zasięgu społecznym" ["The Internet Forum: (Cyber)communication of a Limited Scope of Social Impact"]. In Język w internecie. Antologia [Language on the Internet: Anthology], red. M. Kita and I. Loewe. Katowice: Wydawnictwo Uniwersytetu Śląskiego, 230-242.

Kępa-Figura, D. 2009. “Gry językowe we współczesnej komunikacji medialnej - semantyczna i pragmatyczna analiza języka mediów" ["Language Games in Contemporary Media Communication”]. Prace Językoznawcze Uniwersytetu Warmińsko-Mazurskiego 11: 95-113.

Kępa-Figura, D. 2011. "Wnioskowanie ukierunkowane kontekstem pragmatycznym w komunikacji medialnej” ["Pragmatic Reasoning in Media Communication"]. In Nowe zjawiska w języku, tekście i komunikacji III. Kontekst a komunikacja [New Phenomena in Language, Text and Communication III: Context and Communication], red. I. Matusiak-Kempa, S. Przybyszewski. Olsztyn: Wydawnictwo Centrum Badań Europy Wschodniej UWM w Olsztynie, 279-291.

Kita, M. 2005. Językowe rytuaty grzecznościowe [Politeness Rituals in Language]. Katowice: Wyższa Szkoła Zarządzania Marketingowego i Języków Obcych w Katowicach.

Koszembar-Wiklik, M. 2015. "Media społecznościowe w zarządzaniu komunikacją uczelni ze studentami" ["Social Media in Managing University's Communicaiton with the Students"]. Kultura - Media - Teologia 21: 9-22.

Leech, G.N. 1983. Principles of Pragmatics. London-New York: Longman.

Levinson, P. 2010. Nowe media [New Media]. transl. M. Zawadzka. Kraków: Wydawnictwo WAM.

Marcjanik, M. 1990. "Normy regulujące językowe zachowania grzecznościowe" ["Norms Regulating Language Politeness Behaviour"]. Przeglad Humanistyczny 7: 77-82.

Marcjanik, M. 1993a. "Etykieta językowa" [Language etiquette]. In Współczesny język polski [The contemporary Polish language], (ed.) J. Bartmiński. Wrocław: Wiedza o Kulturze, 271-281.

Marcjanik, M. 1993b. "Granice polskiej grzeczności językowej" ["Limits of Polish Language Etiquette"]. Poradnik Językowy 7: 375-383. 
Marcjanik, M., ed. 2001a. W kręgu grzeczności. Wybór prac z zakresu polskiej etykiety językowej [About Politeness: Selected Works on Polish Langauge Etiquette]. Kielce: Wydawnictwo Akademii Świętokrzyskiej.

Marcjanik, M. 2001b. "Zmiany w etykiecie językowej ostatnich lat XX wieku" ["Changes in Linguistic Etiquette in the Last Years of the 20th Century"]. In Zmiany w publicznych zwyczajach językowych [Changes in Public Language Habits], red. J. Bralczyk and K. Mosiołek-Kłosinska. Warszawa: Rada Języka Polskiego przy Prezydium PAN, 79-84.

Marcjanik, M. 2007. Grzeczność w komunikacji językowej [Politeness in Language Communication]. Warszawa: Wydawnictwo Naukowe PWN.

Marcjanik, M. 2008. "Wielkie zmiany przyjdą jutro. O przemianach w językowych obyczajach grzecznościowych" ["Great Change Will Come Tomorrow. On the Changing Patterns of Politneness in Language"]. Język a kultura 20: 89-98.

Marcjanik, M. 2015/2016. Wykład wygłoszony na inauguracji roku akademickiego 2015/2016 na Wydziale Dziennikarstwa i Nauk Politycznych Uniwersytetu Warszawskiego [2015/2016 Inaugration lecture delivered at the Dept. of Journalism and Political Sciences, University of Warsaw] (March 15, 2019).

Naruszewicz-Duchlińska, A. 2009. "O internetowych dobrych obyczajach językowych, tzw. netykiecie, na przykładzie grup dyskusyjnych (Usenetu)" ["On Language Etiquette on the Internet: The Case of Netiquette in Discussion Groups (Usenet)"]. In Norma a komunikacja [Norm and Communication], red. M. Steciąg and M. Bugajski. Wrocław: Oficyna Wydawnicza Atut-Wrocławskie Wydawnictwo Oświatowe, 219-226.

Naruszewicz-Duchlińska, A. 2011. Internetowe grupy dyskusyjne. Analiza językowa i charakterystyka gatunku [Internet Discussion Groups. Language Analysis and Genre Specification]. Olsztyn: Uniwersytet Warmińsko-Mazurski w Olsztynie.

Naruszewicz-Duchlińska, A. 2019. Kultura zachowań językowych w internecie [The Culture of Language Behaviour on the Internet]. Warszawa: Wydawnictwo Naukowe PWN.

Norwa, A. 2014. "Formuły grzecznościowe w korespondencji elektronicznej studentów do pracowników uniwersytetu" ["Forms of Politeness in Electronic Messages of Students to University Staff Members"]. Media - Kultura - Komunikacja Społeczna 10 (3): 11-27.

Ożóg, K. 1990. Zwroty grzecznościowe wspótczesnej polszczyzny mówionej (na materiale języka mówionego mieszkańców Krakowa) [Forms of Politeness in Contemporary Spoken Polish (The Case Study of the Spoken Language of the Citizens of Krakow]. Warszawa-Kraków: Państwowe Wydawnictwo Naukowe.

Ożóg, K. 2001. Polszczyzna przetomu XX i XXI wieku. Wybrane zagadnienia [The Polish Language at the Turn of the 21st Century. Selected Issues]. Rzeszów: Stowarzyszenie Literacko-Artystyczne "Fraza".

Ożóg, K. 2007. “Uwagi o współczesnej polskiej grzeczności językowej” ["Remars on Conemporary Polish Langauge Politeness”]. In K. Ożóg, Polszczyzna przełomu XX i XXI wieku. Wybrane zagadnienia [The Polish Language at the Turn of the 21st Century. Selected Issues]. Rzeszów: Stowarzyszenie Literacko-Artystyczne "Fraza", 77-88.

Podviazkina, A. 2020. "Polilog w mediach społecznościowych - tematyczna struktura tekstu a grzeczność językowa" ["Polylog in Socia Media - The Thematic Text Structure and Language Politeness"]. Prace językoznawcze XXII (4): 121-138.

Sikora, K. 2010. Grzeczność językowa wsi, cz. 1: System adresatywny [Language Politeness in Rural Areas, part. 1: Forms of Address]. Kraków: Wydawnictwo Uniwersytetu Jagiellońskiego. 
Skowronek, B. 2019. "Media społecznościowe - nowe oblicze komunikacji medialnej?" ["Social Media: A New Face of Media Communication?’]. In Komunikacja ponad granicami. Prace dedykowane profesor Matgorzacie Kicie [Communication Over Barriers: Works Dedicated to Professor Matgorzata Kita], red. M. Czempka-Wiewióra, A. Kalisz, and M. Ślawska. Katowice: Wydawnictwo Gnome, 97-105.

Stownik języka polskiego PWN [Dictionary of Polish by Polish Research Publishing House]. https://sjp. pwn.pl (March 25, 2019).

Wikipedia (March 28, 2021).

Wojtak, M. 2007. “O studenckiej ars epistolandi (pokłosie pewnych ćwiczeń z kultury języka)” [“On Students Ars Epistolandi - An Outcome of Classes in Language Culture"]. In Na językoznawczych ścieżkach. Prace ofiarowane Profesorowi Jerzemu Podrackiemu [Pathways of Language Studies], red. A. Mikołajczuk, and R. Pawelec. Warszawa: Wydawnictwo Naukowe Semper, 62-67.

Żurek, A. 2008. "Teorie grzeczności językowej” ["Theories of Langauge Politeness"]. Acta Universitatis Wratislaviensis. Ksztatcenie Językowe 7 (17): 33-43.

\section{Grzeczność językowa w polskich mediach społecznościowych - zarys problemu}

Słowa kluczowe: grzeczność językowa, media społecznościowe.

\section{STRESZCZENIE}

Celem artykułu jest sformułowanie zasad grzeczności językowej, obowiązujących w polskich mediach społecznościowych (dalej MS). By zminimalizować ryzyko błędu badawczego, bezpośredniej analizie poddano przykładową stronę najpopularniejszego w Polsce serwisu społecznościowego Facebook. Przeprowadzone analizy pokazały, że: na kształt grzeczności wpływają m.in. techniczne możliwości medium; akceptowanymi zachowaniami komunikacyjnymi jest mówienie o sobie samym i formułowanie pośrednich aktów mowy; za równorzędne uznawane są komunikaty werbalne i pozawerbalne; najważniejsze kulturowe zasady grzecznościowe to nastawienie na szczerość rozmowy i prześmiewczy stosunek do rzeczywistości; choć przejawy tradycyjnego modelu grzeczności i modelu obowiązującego w MS różnią się, to oba modele opierają się na tym samym skrypcie komunikacyjnym - dostosowaniu się do oczekiwań odbiorcy. 